\title{
Pastoralno-katehetska dimenzija biskupske službe u dokumentima pape Franje
}

\author{
STANISLAV ŠOTA* \\ UDK: 27-46-722.52Franciscus, papa • Pregledni članak \\ Primljeno: 20. rujna 2017. • Prihvaćeno: 26. siječnja 2018.
}

Sažetak: U radu se analizira poimanje pastoralne i katehetske dimenzije biskupske službe u dokumentima pape Franje. $U$ četiri dijela rad prikazuje sadržaj i obilježja biskupskoga pastoralnoga i katehetskog djelovanja, način njegova ostvarenja te konkretnog doprinosa. Govoreći prvotno o isusovskoj dimenziji biskupskog pastoralno-katehetskog djelovanja, rad analizira, »zaustavlja se « na Isusovu licu kao slici i sinonimu potrebnog biskupskog evangelizacijskog zanosa, žara i preobrazbe. Isusovo je preobraženo lice poziv, poslanje i potreba evangelizacijske, pastoralne $i$ katehetske preobrazbe. Isusovo

${ }^{*}$ Doc. dr. sc. Stanislav Šota, Katolički bogoslovni fakultet u Đakovu, Sveučilišsta J. J. Strossmayera u Osijeku, P. Preradovića 17, 31400, Đakovo, Hrvatska, stanislav. sota@os.t-com.hr lice govori o nužnoj prožetosti isusovskim načelima i biskupskim vrijednostima, nužnosti svjedočanstva i konkretnoj ljubavi ukorijenjenoj u pastoralnom i katehetskom djelovanju. Drugi dio rada donosi konkretne zadaće biskupske službe u pastoralnom $i$ katehetskom smislu: inkorporacija Evandelja $u$ društveno-kulturne sredine, stvaranje novih modela pastoralno-katehetskog djelovanja, promicanje misijskog zajedništva, preispitivanje tradicije, nadvladavanje $\gg$ seoskog sindroma $<$ pastoralno-katehetskog djelovanja, potreba ostvarivanja biskupske službe dimenzijom »Isusa građanina « te »izlaska « na periferije, osobito kvalitetniji pastoral obitelji. U trećem dijelu autor analizira pastoralno-katehetske postavke biskupske službe kroz prizmu snažnije inkulturacije, aktivnog, a ne reaktivnog pastoralno-katehetskog djelovanja, nadvladavanje ateističke $i$ antieklezijalne kulture suvremenog čovjeka, potrebe očuvanja originalnih načina inkorporacije Evandelja u društvo te potrebnu snažniju pastoralnu i katehetsku inkulturacijsku zauzetost biskupa u vlastitoj dijecezi. Četvrti dio rada ukazuje na socijalnu dimenziju pastoralno-katehetskog djelo- 
vanja biskupa, ističući potrebu inicijative biskupa u nadvladavanju u svijetu prisutnog zla i siromaštva, lišavanju i uklanjanju njihovih posljedica, ukazivanju na njihove strukturalne uzroke, $u$ brizi osiguravanja zdravstvene skrbi za svakog čovjeka, dostojanstva rada, pravedne plaće, zaštite dostojanstva ljudskoga života, doprinosa i širenja socijalnog dijaloga, kao bitnoj dimenziji mira i općeg dobra u svijetu.

Ključne riječi: papa Franjo, pastoralna i katehetska dimenzija biskupske službe, isusovsko lice biskupske službe, inkulturacija, socijalna dimenzija pastoralnog i katehetskog djelovanja.

\section{Uvod}

Neovisno o načinu njezina određivanja, dodjeljivanja i primanja, temelj je svake službe u Crkvi služenje: »Tako i Sin Čovječji nije došao da bude služen, nego da služi i život svoj dade kao otkupninu za mnoge « (Mt 20, 28). Izgradnja Kraljevstva nebeskog utemeljena je na dimenzijama služenja, što je u suprotnosti sa 'svijetom i njegovom vlašću' koja se temelji na vladanju i moći: »Kraljevi gospoduju svojim narodima i vlastodršci nazivaju sebe dobrotvorima. Vi nemojte tako! Naprotiv, najveći među vama neka bude kao najmlađi; i predstojnik kao poslužitelj. Ta tko je veći? Koji je za stolom ili koji poslužuje? Zar ne onaj koji je za stolom? A ja sam posred vas kao onaj koji poslužuje « (Lk 22, 25-27). Sve službe u Crkvi trebaju biti prožete upravo karakteristikama Isusova služenja. ${ }^{1} \mathrm{Na}$ audijenciji 22 . studenoga 2013. godine papa je Franjo ustvrdio: »Evangelizacija je poslanje Crkve, i to ne samo nekih, nego moje, tvoje, naše poslanje $\ll_{.}^{2}$ Bilo da je osobno ili zajednički postavljeno, koncipirano, osmišljeno, planirano i programirano, pastoralno djelovanje i kateheza nisu ništa drugo nego sam pastoralni radnik - kateheta na njivi Gospodinovoj. Pisac biografije pape Franje, Andrea Tornielli, smatra da je za razumijevanje pape Franje potrebno krenuti od župne crkve Nuestra Senora Caacupe oslikane muralima ${ }^{3}$ jer naglaske povezane s pastoralnom i katehetskom dimenzijom biskup-

\footnotetext{
${ }^{1}$ Usp. J. SOBRINO, Temelj svih crkvenih služba, u: Concilium 156(2010.)1, 13.-27., ovdje 20.-21.

${ }^{2}$ http://w2.vatican.va/content/francesco/hr/audiences/2013/documents/papa-francesco 20131120_udienza-generale.html (11.6.2017.)

${ }^{3}$ Usp. A. TORNIELLI, Jorge Mario Bergoglio. Papa Franjo. Cjelovita biografija - život, ideje i poruke, Split, 2013., 140. Tako npr. neke od slika prikazuju fratre kako sjede među domorocima i evangeliziraju ih: jedan pokazuje križ i prstom u nebo, drugi pokazuje kip BDM. Druga slika na zidu, mural, pokazuje kako majka drži dijete dok drugo, starije dijete, pokazuje kip BDM mlađem, trećem djetetu. Treća slika pokazuje domoroca kako urezuje lik BDM u drvetu koje je prethodno odrezao s nekolicinom prijatelja. https://www.google.hr/search?q=Nuestra+Senora+Caacupe+mural\&rlz $=1$ C1AVSA_enHR436HR437\&tbm $=i s c h \&$ tbo $=u \&$ source $=$ univ\&sa $=X \& v e d=0$ ahUKEwidisHY3 ZXVAhUBtBoKHUukDwwQsAQIIg\&biw=1600\&bih=794\#imgdii=PzQAsUoxCOp8XM:\&img rc $=69$ myKSj57LicsM (19. 7. 2017.)
} 
ske službe u njegovim dokumentima nužno treba promatrati kroz prizmu snažne inkulturacije. ${ }^{4}$ Papa Franjo također ključnim smatra i osobnu biskupovu prisutnost u vjerničkoj svakodnevici te upravo u takvim okolnostima potrebu evangeliziranja i katehiziranja. Smatra kako pri toj zadaći treba biti neizostavno neposredan u ophođenju s vjernicima, što se mora očitovati u bliskosti s njima, dijeljenju i življenju njihovih života te izbjegavanju odvajanja i udaljavanja od njih. Na tom tragu, inkulturacija uvoznog vjeronauka mora postati prošlost, osobito u katehetskom djelovanju. Stoga papa Franjo sugerira snažnu želju za promjenama u Crkvi, obratom $\mathrm{u}$ evangelizacijskom djelovanju, prementalizacijom u pastoralnom i katehetskom životu i radu svih kršćana, posebice evangelizatora, a time i biskupa kao nositelja pastoralnoga i katehetskog djelovanja.

U aktualnoj situaciji u kojoj je sve manje masovne sakramentalizacije, vjerska permisivna praksa sve je prisutnija, bezdogmatska kršćanska humanost prožima živote mnogih kršćana, a zbunjenih i pogubljenih »ovaca doma Izraelova « (usp. Mt 10, 6: »Pođite radije izgubljenim ovcama doma Izraelova.«) sve je više. Papa s ciljem nadahnjujuće uvjerljivosti očekuje evanđeoski radikalizam, ispovijedanje Krista raspetoga i uskrsnuloga te jednostavnost i neupitnu neposrednost u naviještanju vjere, posebice od strane predvoditelja župnih i biskupijskih zajednica.

U tom kontekstu i Dekret o pastirskoj službi biskupa II. vatikanskog koncila Christus Dominus kaže kako su biskupi ${ }^{5}$ po daru Duha Svetoga $\gg$ prvi i autentični učitelji vjere, svećenici i pastiri $\ll^{6}$. Dakle, pastoralna i katehetska dimenzija biskupske službe povjereni je dar koji je svaki od biskupa pozvan razvijati, njegovati i u povijesnoj konkretnosti ostvarivati snagom Duha Svetoga. Zato papa Franjo od biskupa očekuje da dar službe primljene od Duha Svetoga ostvaruju kroz dimenzije suodgovornosti, kolegijalnosti ${ }^{7}$, supsidijarnosti, sinodalnosti, a posebice komplementarnosti i suglasja u eklezijalnoj, pastoralnoj i katehetskoj povezanosti s prezbiterima i angažiranim vjernicima. ${ }^{8} \mathrm{U}$ tom smislu kardinal Walter Kasper, na tragu promi-

${ }^{4}$ Živko Kustić piše: »Evangelizacija mora biti povezana i usklađena s inkulturacijom, što znači da u svakoj konkretnoj sredini obnovljeno kršćanstvo mora postati duhovnim izazovom baš te sredine «. Ž. KUSTIĆ, Vjeroučitelj i nova evangelizacija, u: Kateheza 16(1994.)2, 111.-121., ovdje 114.

${ }^{5}$ Pojam episkopos upotrebljavali su Grci osobito kad su govorili o bogovima koji bdiju nad ljudima. Biblija ga primjenjuje i na Boga i na Krista. Odatle slika pastira koji se brine za druge, koji ih pase, brani i vodi u život.

${ }^{6}$ DRUGI VATIKANSKI KONCIL, Christus Dominus. Dekret o pastirskoj službi biskupa u Crkvi (28. X. 1965.), br. 2, u: Dokumenti, Zagreb, ${ }^{4} 1986 .(=C D)$.

${ }^{7}$ Više o naravi kolegijaliteta, suodnosa pape, biskupskih konferencija, biskupa mjesnih Crkava na doktrinarnoj i pastoralnoj razini, usp. G. ZIZOLA, Biskupske konferencije, ograničeni kolegijalitet, u: Svesci 26(2000.)99, 66.-80.

${ }^{8}$ Usp. CD, br. 4-18. 
šljanja pape Franje, definira pastoralnu i katehetsku dimenziju biskupske službe kao prakticiranje majčinstva Crkve, koja rađa, doji, pomaže rasti, ispravlja, hrani i vodi vjernike za ruku. ${ }^{9}$ U suglasju je s tim i ekleziologija pape Franje usmjerena decentralizaciji Crkve, jačanju biskupijskih konferencija i legitimnoj relativnoj samostalnosti mjesnih Crkava. Revizionizam i reorganizacija, novi zanos, žar i zamah sadašnjega crkvenog djelovanja za papu Franju nasušna je potreba. U tom smislu znakovite su riječi biskupa Mije Škvorca o razlozima čestoga neuspjeha u obavljanju biskupske pastoralno-katehetske službe, o čemu on kaže kako $\gg($ Crkva) nikada nije imala posebne muke s pojmom i značenjem biskupske službe, sve dok nije protestantska bura uništila svećenički i biskupski red. Crkva je daleko više muke imala s pravovjerjem, apostolskim radom i moralnim životom svojih biskupa, negoli sa shvaćanjem njihove misije i posvete $\ll .{ }^{10}$ Prema pastoralnom teologu Josipu Balobanu, papa Franjo izravno i ciljano posebno od biskupa traži služenje i poniznost kao temelj vršenja biskupske službe, nasuprot gotovo redovito prisutnom fenomenu traženja časti, vlasti, moći te želji za karijerom unutar Crkve koja je sama sebi svrhom. ${ }^{11}$ Walter Kasper smatra kako je papu Franju nemoguće smjestiti u jedan određeni teološki pravac jer je on jednostavno osoba susreta i osebujnog pristupa, budući da svoja teološka promišljanja temelji na pastoralnom iskustvu obilježenom specifičnostima Europe i Argentine u kojima je studirao i živio pri čemu, kao temelj njegova nauka, kao neophodna izvire prisutnost osobnosti. Tako i biskupovu službu, što je posebno vidljivo u njegovim Pobudnicama, ${ }^{12}$ tumači očima teologa Yvesa Congara koji kaže: »Biskupska služba ima istodobno i kristološku i pneumatološku dimenziju: od Krista dobiva svoje poslanje, a Duh joj Sveti ujedinjuje učinkovitost. $\ll{ }^{13}$ Promišljajući o predstavljenoj problematici u okviru teološkog promišljanja izloženog u dokumentima pape Franje, rad u prvom dijelu govori o isusovskom licu biskupske pastoralno-katehetske službe, drugi dio raspravlja o pastoralno-katehetskoj dimenziji biskupske službe, treći o inkulturaciji Evanđelja kao temeljnoj zadaći biskupske službe, a četvrti, ujedno posljednji, o socijalnoj dimenziji biskupske pastoralno-katehetske službe.

\footnotetext{
${ }_{9}^{9}$ Usp. W. KASPER, Papa Franjo. Revolucija nježnosti i ljubavi, Zagreb, 2015., 60.

${ }^{10}$ M. ŠKVORC, Jeruzalem ili Antiohija, Zagreb, 1988., 333.

${ }^{11}$ Usp. J. BALOBAN, Mentalni sklop pastoralnih djelatnika i pontifikat pape Franje, u: Bogoslovska smotra 87(2017.)1., 33.-58., ovdje 38.

${ }^{12}$ Usp. FRANJO, Evangelii gaudium, Zagreb, 2013. (= EG); FRANJO, Amoris laetitia, Zagreb, 2016. (=AL).

${ }^{13}$ Y. CONGAR, Služba i karizma, u: Svesci 21(1997.)89-90, 69.-73., ovdje 71.
} 


\section{Isusovsko lice biskupske pastoralne i katehetske službe prema papi Franji}

Olegario Gonzales de Cardedal, govoreći o biskupskoj službi u svjetlu II. vatikanskog koncila, ističe: »Posljednji je Koncil stavio biskupa u središte svojeg nauka o Crkvi. Treba dakle, da postanemo svjesniji što je i što bi trebao biti biskup. Treba očistiti biskupsku službu od svih nedostataka i nesavršenosti koji je unakazuju. $\ll^{14}$ Za njega izrečena tvrdnja znači da Crkva i biskupi ne smiju zaboraviti bit, poslanje, podrijetlo i narav biskupske službe, posebice imperativ vraćanja i posadašnjenja biskupske službe u svjetlu Prve Crkve. U tom smislu biskupsku službu potrebno je promatrati i razumijevati imajući u vidu četiri osnovne stvarnosti, odnosno četiri temelja biskupske službe: Crkvu, apostole, Krista i mjesne Crkve. ${ }^{15}$ Sadržaj i izričaj navedenih stvarnosti utemeljuju biskupa kao vicarius Christi in Ecclesia. ${ }^{16}$ Sveti Ciprijan za (su)odnos Crkve, biskupa i biskupske službe kaže: »Crkva u biskupu i biskup u Crkvi. $\ll{ }^{17}$ Biskupsku službu i biskupa u pastoralno-katehetskom smislu može se, stoga, definirati kao onoga koji in persona Christi autoritetom stvara Crkvu onoliko koliko je zaštićuje od samovolje pojedinca, onoga koji Isusovim autoritetom Crkvu evangelizacijom rađa, brine se za Evanđelje, koji se konkretnom isusovskom ljubavlju zauzima i živi za ljude koji su prihvatili Evanđelje i žive u crkvenoj zajednici. U pastoralnom i katehetskom poslanju svakog evangelizatora, posebice biskupa, za papu Franju neizostavan je govor o značenju, srži, biti, naravi i posebice zagledanosti u Isusovo lice tijekom njegova navještaja i evangeliziranja. Budući da je Isusovo lice sinonim Isusove osobnosti, žara, zanosa i preobrazbe (usp. Mt 17, 1-13), svaki evangelizator, posebice biskup kao predvoditelj mjesne Crkve, pozvan je svima koji slušaju njegovo svjedočanstvo približavati preobraženo Isusovo lice, $u$ njega biti zagledan, njime evangelizirati, biti prožet njegovim žarom i zanosom. Dakle, za papu Franju lice je sinonim za osobnost evangelizatora koji je prožet Isusom Kristom, a time i osnovni potrebni znak i kvaliteta biskupske pastoralno-katehetske službe. ${ }^{18}$ Lice evangelizatora obveza je koja poziva na odgovornost za bližnjega koji stoji nasuprot. Dok sami (ne) svjedočimo i (ne) evangeliziramo, u susretima i traženju na licima drugih nalazimo (ne)odsjaj Božjeg lica. Snaga (ne)preobražena lica i evangelizacije evangelizatora, posebice biskupa, za papu Franju ima uspjeha,

\footnotetext{
${ }^{14}$ O. G. de CARDEDAL, Što je biskup?, u: Svesci 3(1980.)39, 48.-57., ovdje 56.

${ }^{15}$ Prema de Cardedalu Crkva, Krist, apostoli i mjesna Crkva u neraskidivom (su) odnosu da svaki i najmanji vid okrnjenosti jednog od temelja biskupsku službu čine $\gg$ izobličenom ili deformiranom $\ll$. Usp. O. G. de CARDEDAL, Što je biskup?, 49.-50.

${ }^{16}$ Isto, 50 .

${ }^{17}$ Isto, 52 .

${ }^{18}$ Usp. EG, br. 88 .
} 
odnosno neuspjeha. ${ }^{19}$ Tako Baloban kaže: »kao Božji sanjar i kršćanski vizionar rimski biskup stalno se vraća na autentično isusovsko i evanđeosko lice Crkve od kojega jednostavno ne odustaje kako u zgodno tako i u nezgodno vrijeme $\ll^{20}$. U tom kontekstu znakoviti su beskompromisni izričaji pape Franje na tradicionalnom susretu s djelatnicima Rimske kurije tijekom kojega je »imenovao petnaest svojevrsnih bolesti Kurije $\ll^{21}$, proširujući ih na sve razine u Crkvi, posebice na biskupije i biskupe, te svećenike. Dijagnoza stanja $\gg$ Rimske kurije, Crkve u malom $\ll^{22}$, kako ju je definirao papa Franjo, u velikoj mjeri otežava i oslabljuje pastoralnu i katehetsku dimenziju biskupske službe. Zbog toga poznavatelje nastojanja pape Franje ne treba čuditi tako snažan naglasak na Isusovu licu u evangelizaciji, jer bez misijske, evangelizacijske, pastoralne i katehetske preobrazbe biskupa kao prvih evangelizatora, kateheta, pastira i svećenika, neprimjetno, ali sustavno i vrlo brzo, napušta se izvor svakog djelovanja, Isusov misijski žar i zanos. ${ }^{23} \mathrm{Uz}$ nužnost napuštanja $\gg$ pastorala groba $\ll^{24}$, autoreferencijalnosti ${ }^{25}$, birokracije, puke administracije, pastorala očuvanja ${ }^{26}$, zatvorenosti $\mathrm{i} \gg$ lutanja bez korijena $\ll{ }^{27}$, po njemu je misijska preo-

${ }^{19}$ Za papu Franju lice je sinonim osobnosti, žara, zanosa, preobrazbe, ljubavi. Usp. FRANJO, Miseriecordiae vultus, Zagreb, 2015., br. 1-3, 8-12.

${ }^{20} \mathrm{~J}$. BALOBAN, Mentalni sklop pastoralnih djelatnika i pontifikat pape Franje, 51.

${ }^{21}$ Naveo je sljedeće: osjećaj besmrtnosti i važnosti, pretjerani rad, psihička i duhovna zatupljenost, pretjerano planiranje, loša koordinacija, duhovni Alzheimer, rivalstvo i taština, egzistencijalna shizofrenija, ogovaranje i zavjere, idoliziranje nadređenih, neosjetljivost prema drugome, bolesnopogrebski izraz lica, potreba za posjedovanjem, bolest zatvorenih kružoka, potreba za svjetovnim profitom i egzibicionizam. Usp. Presentation of the Christmass greetings to the Roman Curia. Address of His Holines pope Francis, (22. 12. 2014.), br. 1-9, http://w2.vatican.va/content/francesco/en/ speeches/2014/december/documents/papa-francesco_20141222_curia-romana.html (10. 8 . 2017.)

${ }^{22}$ Usp. Papa imenovao 15 »bolesti« Rimske kurije - među njima su materijalizam, ogovaranje, taština, 1.-3., https://www.bitno.net/vijesti/vatikan/papa-imenovao-15-bolesti-rimske-kurije-medu-njimasu-materijalizam-ogovaranje-tastina/ (11.8.2017.)

${ }^{23}$ Usp. EG, br. 30.

${ }^{24} \mathrm{U}$ dokumentu papa govori o »psihologiji groba « koja je prisutna u pastoralnom djelovanju prožetom bezličnim pragmatizmom u Crkvi. U tom kontekstu navedeno pastoralno djelovanje možemo okarakterizirati kao »pastoral groba «, jer takvo pastoralno djelovanje »ide svojim tijekom «, odrađen, i ne postavlja si pitanje zašto vjera sve više slabi i zapada u sve jadnije stanje. Za papu se takvi kršćani malo po malo pretvaraju »u mumije iz muzeja «. (Isto, br. 83.)

${ }^{25}$ Usp. isto, br. 8.

${ }^{26}$ Pastoral očuvanja, odnosno čuvanja, riječi su južnoameričkih biskupa koje je papa Franjo često upotrebljavao kako bi ukazao na prisutnu pastoralno-katehetsku pojavu u kojoj evangelizatori »mirno i pasivno « čekaju da im netko dođe, zaboravljajući Isusov nalog izrečen apostolima: »Idite $($... $)$ usp. Mk 16, 15; usp. EG, br. 15 .

${ }^{27}$ Usp. EG, br. 29. 
brazba svake partikularne Crkve pod vodstvom biskupa: »konkretno očitovanje jedne Crkve u jednom dijelu svijeta (...) Crkva inkarnirana u određeni prostor, opskrbljena i opremljena svim sredstvima spasenja koje je dao Krist, s lokalnim obilježjima $\ll^{28} \mathrm{U}$ tom smislu, od biskupa kao prvih evangelizatora, pastoralaca i kateheta očekuje se da ne budu sebi svrhom, utopljeni $\mathrm{u} \gg$ sigurnost doma «, gospodari nad Radosnom viješću, svećenicima i vjernicima laicima, nego sluge milosti zahvaćene pastirskim žarom, vjerom, osobnim predanjem i služenjem. ${ }^{29}$ Današnja kultura »zahtijeva $(. .$.$) dušobrižništvo s isusovskim licem, kulturom srca i susrete$ prožete empatijom i ljubavlju. Zahtijeva da dušobrižnik bude današnjem čovjeku most, a ne zapreka do Isusa i do Boga ( ... ) Želi promjenu mentalnog sklopa svećenika i biskupa i naroda Božjega, ističući da se ne bave sami sobom, nego čovjekom pokraj sebe. Jednom riječju, na djelu je nova kultura pastorala. ${ }^{30}$

U pobudnicama Evangelii gaudium i Amoris laetitia iščitavaju se (ne)evanđeoske dimenzije biskupske službe ne samo na institucionalnoj razini s gledišta birokracije i diplomacije, već i s gledišta pastoralne i katehetske stvarnosti:

a) Autoritativni vid - biskup uvijek vrši službu kao posljednja nadležnost svakom događaju i dimenziji života mjesne Crkve. Takav se biskup ne poziva na druge i ne uvažava druge osobe, službe, karizme, institucije i instance. ${ }^{31}$

b) Demokratski vid - stav u kojem neotuđivi autoritet i odgovornost svojstvenu biskupskoj službi biskup uvijek prepušta drugima: suradnicima, statističkim podatcima, pastoralnoj sociologiji, istraživanjima, anketama, i to bez osobne prosudbe i osobnog odlučivanja, sve prihvaća bez osobne odgovornosti i osobnog angažmana. $^{32}$

${ }^{28}$ Isto, br. 30.

${ }^{29}$ Usp. J. BALOBAN, Mentalni sklop pastoralnih djelatnika i pontifikat pape Franje, 52.

${ }^{30}$ Usp. isto, 39.

${ }^{31}$ Autoritativni vid najlakše iščitavamo u govoru pape Franje o biskupovoj dužnosti da promiče misijsko zajedništvo u vlastitoj dijecezi, u kojem on ističe kako pojedini, umjesto da pastoralno dijalogiziraju sa svima, »slušaju samo neke, koji su uvijek spremni reći ono što biskup želi čuti«. (Usp. EG, br. 31.) Papa ne želi ni od vjernika, svećenika, osobito biskupa u evangelizacijsko-pastoralnom djelovanju izbjegavanje, skrivanje, zatvaranje u sebe radi svojih interesa samoostvarenja vlastitih ciljeva. Takav je stav u pastoralno-katehetskom djelovanju prema papi Franji »evangelizacijsko samoubojstvo «. (Usp. isto, br. 272.) Autoritativni vid iščitava se i u uputi pape Franje biskupima: $\gg$ Nije uputno da papa zamjenjuje mjesne biskupe u raspoznavanju svih problematika koje se javljaju na njihovim teritorijima. U tome smislu primjećujem nužnost da se pristupi zdravoj decentralizaciji.« (Usp. isto, br. 16.) Pretjerana centralizacija, umjesto da pomogne, komplicira život Crkve i njezinu misijsku djelatnost. (Usp. isto, br. 32.)

${ }^{32}$ Demokratizacijski vid prisutan je u govoru pape Franje o $\gg$ Crkvi izlaska « koja ne trči bezglavo i besciljno za svijetom, ne juri s jednog posla za drugim, koja je otvorena za druge, ali s ciljem ne 
c) Tehnokratski vid - odnosi se na realno stanje prožeto usponima i padovima, uspjesima i neuspjesima u pastoralnom smislu. »Tehnokratski biskup « zamjenjuje evangelizaciju naizgled $\gg$ savršeno organiziranim pastoralnim i katehetskim djelovanjem «. Tehnokratski pristup po svojoj naravi nije u mogućnosti uvidjeti i prepoznati realno stanje, nego kroz naizgled savršen tehnokratskofunkcionalni pristup i djelovanje, uvijek ili gotovo uvijek, umnaža birokratski aparat, stvarajući odsjeke, urede, povjerenstva i tajništva u kojima vjernik, kojemu je sam biskup poslan, nije na prvom mjestu ili jednostavno ne postoji. Takav je biskup okružen suradnicima - istomišljenicima. ${ }^{33}$ Papa Franjo ne naziva samo pastoralno i katehetsko djelovanje tehnokratskim pastoralom i katehezom nego i teologiju drži uredskom teologijom. ${ }^{34}$

d) Proročka izoliranost i usamljenost ${ }^{35}$ - devijacija u kojoj biskup shvaća službu i živi tako da osluškuje isključivo osobno vjersko iskustvo, a u mjesnu Crkvu nije spreman integrirati vjersko iskustvo, službe i doprinose bližnjega; nije sposoban slušati, razgovarati, komunicirati vjeru s bratom, suradnikom, vjernikom i vremenom u kojem živi. ${ }^{36}$

prepustiti ih samima sebi nego imati hrabrosti susretati ih, slušati, razumjeti, najmanje dopustiti da $\gg$ sami sebe vode « te besciljno i destruktivno koračaju životom. Pastoralno-katehetska dimenzija biskupske službe pretpostavlja sadržaj, metodu, način i cilj duhovnog vodstva. (Usp. isto, br. 46-48.) Demokratizacijski vid biskupske službe najjasnije je okarakteriziran riječima pape Franje: »Moje poslanje, koje se sastoji u tome da budem usred naroda, nije dio moga života, privjesak koji mogu skinuti, nije dodatak ili tek jedan od mnogih trenutaka života.«(Isto, br. 273); kao i u tvrdnji da današnji evangelizatori sliče »generalima poraženih vojski«. (Usp. isto, br. 96.) Tvrdnja pape Franje kako »gubimo vrijeme na razgovore o 'onome što bi se trebalo učiniti' - grijeh 'trebalo bi se učiniti' - kao duhovni učitelji i stručnjaci za pastoral koji daju upute s vrha, ali se sami ne upuštaju $\mathrm{u}$ to $\ll$, također potvrđuju gore navedenu tvrdnju. (Usp. isto.)

${ }^{33}$ Evangelizacija, pastoralno i katehetsko djelovanje okarakterizirano kao »korizma bez Uskrsa « (usp. isto, br. 6); puka administracija, birokracija (usp. isto, br. 25); kao zadaća, intimističko i individualističko pastoralno djelovanje, pastoralno-katehetski rad koji se »mora činiti« (usp. isto, br. 261-262.) Pastoralno-katehetski rad koji nije prikladan za sadašnji trenutak i ne ostvaruje se prikladno, $\gg$ ne preispituje se i ne propitkuje se postojeće stanje, ali se programi stvaraju «. Usp. isto, br. 43. - izrazi su koji potvrđuju tehnokratsku dimenziju biskupske službe. Tehnokratsku dimenziju biskupske službe iščitavamo u riječima: »Unedogled raspredamo o našim maštarijama i gubimo dodir sa stvarnim životom našega ispaćenoga vjerničkoga puka.« (Usp. isto, br. 96.) Izrazi koji potvrđuju tehnokratski vid: »Dijagnostičko pretjerivanje «, »sociološka analiza koja je svrha sama sebi «. Usp. isto, br. 50.

${ }^{34}$ Navedeni autor citira Papu: »nemojte se zadovoljiti jednom uredskom teologijom $(\ldots) \ll$. Usp. H. R. OSORIO, Interpelacija pape Franje današnjoj teologiji, u: Concilium 53(2017.)1, 163.-167., ovdje 163.

${ }^{35}$ O. G. de CARDEDAL, Što je biskup?, 54.

${ }^{36}$ Izrazi »skučenost «, »autoreferencijalnost « (usp. EG. br. 8) i »Evangelizacija koja kopni u osamljenosti (usp. isto, br. 10), izrazi su koji ukazuju na proročku izoliranost i usamljenost življenja i ostvarenja biskupske službe. 
Nadalje, pastoralna i katehetska dimenzija biskupske službe ostvaruje se u isusovskom smislu riječi, pastoriziranjem, naviještanjem i katehiziranjem, po svim krovovima, u svakom vremenu, svakom čovjeku, u svakom trenutku, zbunjenim i vjernim sinovima i kćerima Crkve, onima koji svoju vjeru vole i žive, i onima koji su umorni i opterećeni te potiho napuštaju Crkvu. U pastoralnoj i katehetskoj dimenziji biskupske službe potrebno je voditi se onim što je Isus činio, jer kao što je čovjek put Crkve, tako je Krist Isus mjera i mjerilo pastoralnog i katehetskog djelovanja svima, a osobito nasljednicima njegovih apostola.

\section{Pastoralna i katehetska dimenzija biskupske službe prema papi Franji}

Papa smatra da misijska preobrazba u sebi sadržava proces sustavne i svakodnevne obnove partikularnih Crkava, a biskup je dužan kroz misijsko zajedništvo poticati intenzivniji, velikodušniji i plodniji evangelizacijski žar. Dimenzije misijskog zajedništva biskup je dužan ostvarivati kroz vodstvo različitih vidova ${ }^{37}$ koje se očituje pružanjem nade ministerijalnom i sveopćem svećenstvu, jednostavnom i milosrdnom blizinom svakom čovjeku ${ }^{38}$, stvaranjem kvalitetnog ozračja za pastoralni dijalog unutar partikularne Crkve ${ }^{39}$, osobito $\gg$ evangelizacijsko-misijskim vizionarstvom «, snom u kojem Radosna vijest dopire do svakog čovjeka. ${ }^{40}$ Nadalje, pastirska služba biskupa prema papi Franji najsnažnije se treba očitovati u kvalitetnom, od biskupa i njegovih suradnika osmišljenom »pastoralno-misijskom ključu «. ${ }^{41}$ Papa je mišljenja da kvalitetan misijski ključ propitkuje i analizira evangelizacijske ciljeve, strukture, načine i metode vlastitih zajednica i njihova djelovanja, i to prepoznavanjem, prihvaćanjem i određivanjem konkretnog pastoralnog cilja, izborom načina pastoralnog djelovanja u ostvarivanju određenog pastoralnog cilja te vođenjem brige tijekom ostvarivanja pastoralnog plana i programiranja. U svemu tome ključno je da subjekti pastorala ostanu usredotočeni na bitno, važnije, nužnije i privlačnije, ne gubeći pritom dubinu istinitosti, snagu, uvjerljivost, hijerarhiju istina i

\footnotetext{
${ }^{37} \mathrm{U}$ pobudnici piše $\gg$ ići naprijed da pokaže put « (usp. isto, br. 31 ).

${ }^{38}$ Isto, br. 31.

${ }^{39} \mathrm{O}$ dijalogu kao bitnoj i sastavnoj dimenziji Crkve, dijalogu kao vodilji Drugoga vatikanskog koncila, dokumenta Koncila, zatim dijalogu kao sastavnici života Crkve, a time i evangelizacije, pastoralnog i katehetskog djelovanja usp. H. J. POTTMEYER, Dijaloške strukture u Crkvi i teologija zajedništva (Communio) Drugoga vatikanskog koncila, u: Svesci 39(2013.)116, 20.-31.

${ }^{40}$ Usp. EG, br. 31.

${ }^{41}$ Usp. isto, br. 35.
} 
prioriteta te prikladan osjećaj za mjeru. ${ }^{42} \mathrm{Na}$ temelju rečenoga možemo uočiti kako se pastoralne i katehetske dimenzije biskupske službe očituju u biskupovoj zadaći u vlastitoj dijecezi koja mu je povjerena:

- Biskup je pozvan stvarati nove načine, pristup, modele, »satnice «, »novi jezik govor $\ll i \gg$ kanale « prihvatljive i prilagođene za pastoralno i katehetsko djelovanje. ${ }^{43}$

- Biskup treba pastoralnim i katehetskim razlučivanjem, čišćenjem i obnovom u partikularnu Crkvu unositi svjetlo i život ondje gdje ga najviše nedostaje, ${ }^{44}$ pružati poticaj i osnaživati intenzivniji, velikodušniji i plodniji misionarski žar, promicanjem misijskog zajedništva ${ }^{45} \mathrm{u}$ vlastitoj dijecezi, iskrenim dogovaranjem prikladnih metoda naviještanja Evanđelja. ${ }^{46}$

- Biskup mora nastojati zahtijevati egzistiranje i snažnije djelovanje biskupijskih tijela suodgovornosti, predviđenih Zakonikom kanonskog prava ${ }^{47}$ te poticati na dijalog svih koji su u službi pastoralnog i katehetskog rada. Pozvan je pomno planirati i uvijek biti prvi u evangelizacijskom djelovanju: biti blizak nositelj autentičnog crkvenog nauka. ${ }^{48}$

- Biskupova je zadaća biti osoba autoriteta, u životu i radu prožeta snažnim osluškivanjem svih u partikularnoj Crkvi, a ne samo $\gg$ nekih $\ll$ odabranih. ${ }^{49}$

- U poslanju i zadaći biskupi ne smiju zanemariti preispitivanje tradicije ${ }^{50} \mathrm{i}$ običaja ${ }^{51}$ usko povezanih s pojedinim pučkim pobožnostima, duboko ukorijenje-

${ }^{42}$ Usp. S. ŠOTA, Poimanje kerigmatske i mistagoške kateheze: osobne i pedagoške značajke te tipologija evangelizatora u Evangelii gaudium, u: Crkva u svijetu 51(2016.)1, 120.-142., ovdje 120.-130.

${ }^{43}$ Usp. EG, br. 30.

${ }^{44}$ Usp. isto.

${ }^{45}$ Usp. isto.

${ }^{46}$ Ž. KUSTIĆ, Vjeroučitelj i nova evangelizacija, 118.

${ }^{47}$ Osnivanje Prezbiterskog vijeća, Biskupijskog pastoralnog vijeća, Biskupijskog katehetskog vijeća, Zbora savjetnika, Biskupijskog ekonomskog vijeća, Župnog pastoralnog vijeća, Župnog ekonomskog vijeća. Usp. ZAKONIK KANONSKOG PRAVA, Zagreb, 1996., kann. 460-468; 492-502; 511-514; 536-537.

${ }^{48}$ Više o biskupijskim tijelima suodgovornosti usp. S. ŠOTA, Analiza i kritički osvrt na župna pastoralna vijeća i njihove odbore u Đakovačko-osječkoj nadbiskupiji, u: Obnovljeni život 71(2016.)1, 85.-101.

${ }^{49}$ Papa pod izrazom $\gg$ nekih « misli na sve one koji biskupima govore samo ono što oni misle da bi biskup želio čuti. Isto tako misli i na one koji nisu spremni biti zdravo kritički postavljeni, nego zbog osobne bolesne ambicioznosti prešućuju ili ne govore ono što misle da je potrebno mijenjati, raditi, činiti, govoriti, misijski djelovati. (Usp. EG, br. 31.)

${ }^{50} \mathrm{O}$ odnosu Tradicije $\mathrm{i} \gg$ karizme Istine $\ll$. Usp. A. MERKT, »Služba Tradicije $\ll$ i $\gg$ karizma Istine $\ll, u$ : Svesci 37(2011.)111, 93.-102.

${ }^{51}$ Usp. Y. CONGAR, Autonomija i centralna vlast u Crkvi, u: Svesci 4(1980.)40, 7.-15., ovdje 7.-14. 
nima u povijest, područje i život mjesne Crkve. Pozvani su pomno preispitivati sve spomenute stvarnosti, kako bi se tradicionalni vidovi vjere živjeli i prikladno ostvarivali. ${ }^{52}$

- Biskupska pastoralna i katehetska služba u sebi podrazumijeva i uključuje razboritu distancu $\gg$ ni presporog, ni prebrzog pastoralnog i katehetskog koraka «.53 Pastoralna dijagnostika i pastoralna sociologija dobre su u sebi ukoliko predlažu učinkovite » primjenjive metode lijeka « pastoralnoga i katehetskog stanja, posebice one koje je potrebno pastoralno i katehetski usustaviti, odnosno institucionalizirati. $U$ tom smislu biskupi su pozvani, posebice u prepoznavanju karizmi, ${ }^{54}$ na regionalnoj i nacionalnoj razini, evanđeoskim razlučivanjem koristiti svjetlo i snagu Duha Svetoga kao $\gg$ prvi lijek $\ll .55$

- U ostvarivanju pastoralne i katehetske zadaće biskupi trebaju sačuvati osjećaj za mjeru te, uz cjelovitost, uvijek stavljati središnje istine vjere i kršćanske istine na prvo mjesto, ne ulazeći u periferna pitanja koja su po svojoj naravi više etička, filozofska, psihološka ili pripadaju nekim drugim područjima stvarnosti. ${ }^{56}$

- Pastoralna i katehetska dimenzija biskupske službe u pastoralu braka i obitelji posebno je istaknuta u pobudnici Amoris laetitia jer brak i obitelj moraju postati subjekt pastoralnog djelovanja u Crkvi. ${ }^{57}$ Stoga se pastoralna i katehetska dimenzija biskupske službe treba očitovati u brizi za pastoralne sadržaje predženidbenog i postženidbenog pastorala braka i obitelji. ${ }^{58}$ Slikovitim govorom papa Franjo ističe kako Crkva, pastoralno nastojanje, župne zajednice, pastoralni djelatnici, predvoditelji župnih zajednica, a osobito biskupi, trebaju voditi pastoralnu brigu o svim brakovima i obiteljima. ${ }^{59} \mathrm{U}$ tom kontekstu progovara kako Crkva, biskupi i ostali pastoralni djelatnici današnjim brakovima i obiteljima trebaju biti svjetionik, luka, baklja, poljska bolnica i kvasac. ${ }^{60}$ Osjetljivost, pastoralno razumijevanje i brigu biskupi su dužni očitovati i prema osobama koje se nalaze u neregularnim brakovima i obiteljima, posebice rastavljenima i civilno vjenčanima. Logikom

${ }^{52}$ Usp. EG, br. 43; Y. CONGAR, Autonomija i centralna vlast u Crkvi, 7.-14.

${ }^{53}$ Usp. EG, br. 46-47.

${ }^{54}$ Usp. isto, br. 51.

${ }^{55} \mathrm{O}$ naravi karizme i institucije, osobito o odnosu karizme i institucije vidi u E. D. C'ONNOR, Karizma i institucije, u: Svesci 1(1972.-1973.)21-24, 3.-10. Karizma i institucija moraju biti poput soka i žila drveta - jedna bez druge ne mogu egzistirati. (Usp. isto, 4.)

${ }^{56}$ Usp. EG, br. 38-39.

${ }^{57}$ Usp. AL

${ }^{58}$ Usp. isto, br. 205-229.

${ }^{59}$ Usp. FRANJO, Obitelj je dragocjeno blago, Split, 2015., 121.-136.

${ }^{60}$ Usp. AL, br. 291-292. 
uključivanja, praćenja, razlučivanja i postupnosti, u skladu s naukom Crkve i biskupskim smjernicama, ${ }^{61}$ biskup je dužan animirati predvoditelje župne zajednice - svećenike, odnosno župnike - kako bi kvalitetnije pastoralno djelovali. Pobudnica poseban naglasak u okviru odgovornog pastoralnog razlučivanja stavlja na razabiranje stupnja osobne odgovornosti, stoga predvoditelji župne zajednice moraju obratiti pozornost na (su)odgovornost, osobni rad i praćenje pojedinačnih brakova i obitelji. U tom kontekstu, predvoditelj župne zajednice kroz razgovor in foro interno pozvan je rastavljenima i civilno vjenčanima pomoći u stvaranju ispravnih sudova o zaprekama punom zajedništvu s Crkvom, mogućnostima i uvjetima integriranja u župnu zajednicu, dimenzijama osobne angažiranosti u župnoj zajednici, osvješćivanju i približavanju mogućnosti življenja njihove vjere te osobne duhovnosti. ${ }^{62}$ Prilikom razgovora in foro interno između svećenika te rastavljene i civilno vjenčane osobe svećenik ${ }^{63}$ je dužan utvrditi neke činjenice. Dužan je upitati o ophođenju rastavljenih i civilno vjenčanih s djecom iz prvog braka, utvrditi intenzitet, napor i nastojanje oko mogućeg pomirenja s osobom $\mathrm{s}$ kojom je doživjela bračni brodolom; uočiti kakav je suodnos s bračnim drugom s kojim je savez prekinut; razmotriti posljedice rastave na ostatak obitelji i posljedice koje osjeća zajednica vjernika; također osvijestiti kakav primjer rastavljeni i civilno vjenčani pružaju mladima koji se pripremaju na ženidbu. ${ }^{64}$

Svakom biskupu ideal treba biti život prve Crkve. ${ }^{65}$ Žar, zanos i misionarska preobrazba po svojoj će naravi uvijek pastoralno i katehetsko djelovanje približiti evangelizaciji, pastoralnom i katehetskom duhu »Prve Crkve «, Kristu, a današnju Crkvu, osobito partikularnu, deklerikalizirati, demokratizirati i decentralizirati. ${ }^{66}$ Crkva će tako postati vjerodostojnija i autentičnija prema društvu i svijetu. Pastoralna i katehetska dimenzija biskupske službe, dakle, uvijek mora biti u službi Evanđelja i bližnjega. ${ }^{67}$

${ }^{61}$ Usp. FRANCESCO, Udienza generale, (5. 8. 2015.), http://w2.vatican.va/content/francesco/it/ audiences/2015/documents/papa-francesco_20150805_udienza-generale.html (22.11.2016.)

${ }^{62}$ Usp. S. ŠOTA, Pastoralno djelovanje s rastavljenima i civilno vjenčanima prema pobudnici Amoris laetitia, u: Diacovensia 25(2017.)2, 285.-301., ovdje 294.-299.

${ }^{63}$ Usp. AL, br. 300.

${ }^{64}$ Usp. S. ŠOTA, Pastoralno djelovanje s rastavljenima i civilno vjenčanima prema pobudnici Amoris laetitia, 296.

${ }^{65}$ Usp. EG, br. 31.

${ }^{66}$ Usp. J. BALOBAN, Mentalni sklop pastoralnih djelatnika i pontifikat pape Franje, 53.

${ }^{67}$ Usp. C. van VLIET, Yves Congar: služba i karizma, u: Svesci 21(1997.)89-90, 70.-73. 


\section{Inkulturacija Evanđelja kao osnovni zadatak biskupske službe svakog biskupa}

U posljednjih pedeset godina u teološkom diskursu neprestano se ponavlja misao II. vatikanskog koncila kako je najveća drama našeg vremena raskid između vjere i kulture. ${ }^{68} \mathrm{U}$ tom kontekstu Yves Congar ustvrdio je kako je »katolicizmu nedostajala teologija lokalnih Crkava: postojala je teologija lokalne rimske Crkve, postupno raširene do svjetskih dimenzija (...), a koncepcija lokalnih ili pojedinačnih Crkava bila je manjkava. Baš je tu manjak latinske ekleziologije $(. ..) \ll{ }^{69} \mathrm{Na}$ postavljeno pitanje jesu li na krštenju potrebna tri uranjanja ili je dovoljno jedno, Grgur Veliki Leandru iz Seville odgovorio je: »Kad je ista vjera, svetoj Crkvi ništa ne škode različiti običaji. $\ll{ }^{70} \mathrm{U}$ tom smislu prvo pitanje u promišljanju o pastoralno-katehetskoj dimenziji biskupske službe ide u pravcu mjesta i mogućnosti evangelizacije s obzirom na društvena događanja i povijesno kulturne okolnosti. ${ }^{71}$ Dakle, treba poći od činjenice kako ni u jednom crkveno-povijesnom trenutku nije vladala potpuna harmonija, ali ni potpuni raskorak između $\gg$ Riječi $\ll$, vremena i mjesta. Ideal je uvijek isti - evangelizirati u pravo vrijeme na pravom mjestu. ${ }^{72} \mathrm{U}$ tom smislu inkulturacija je Evanđelja osnovni zadatak biskupske službe u poslanju svakog biskupa. Papa je Franjo uvjeren da raznoliku i oprečnu stvarnost možemo shvatiti jedino u svjetlu Evanđelja, stoga je svima u Crkvi zadaća inkorporirati Evanđelje u današnju kulturu. ${ }^{73}$ On kaže: $\gg$ Evangelizirati kulture radi inkulturacije evanđelja predstavlja imperativ. U zemljama katoličke tradicije to znači da će trebati već postojeće bogatstvo pratiti, skrbiti i jačati. U zemljama drugih religijskih tradicija ili onima koje su duboko sekularizirane to će značiti poticanje novih procesa evangelizacije kulture. $\ll{ }^{74} \mathrm{Zbog}$ fenomenologije kulture koja uključuje raznolikost, promjenjivost i relativnost, papa Franjo ne govori o gotovim receptima, nego, prožet duhom supsidijarnosti i sinodalnosti, modele inkulturacije u procesu evangelizacije prepušta

${ }^{68}$ Usp. M. KNEP, Kultura kao zapreka evangelizaciji, u: Svesci 20(1996.)87-88, 151.-155., ovdje 152.

${ }^{69}$ Usp. Y. CONGAR, Autonomija i centralna vlast u Crkvi, 8.

${ }^{70}$ Usp. isto.

${ }^{71}$ Usp. Š. MARASOVIĆ, Inkulturacija kateheze u socijalizam, u: Kateheza 1(1979.)2, 7.-19., ovdje 17.

${ }^{72}$ Pravo mjesto i pravo vrijeme jest današnja kultura. Pravo mjesto i pravo vrijeme isto je što i kultura.

${ }^{73} \gg$ Kultura je, naime, umjetnost, mediji, gospodarstvo, izobrazba, znanost, socijala, dobročinstvo, politika (... ) Crkva bi morala odvažnije kročiti u sva ta područja. To Crkva, doista, i čini: utemeljuje poduzeća, medijske kuće, škole, Caritas itd. Jedino ne utemeljuje političke stranke. Znači li to da Crkva dijeli kulturu na prljava područja (politika ...), poluprljava (poduzetništvo, bankarstvo) i čista (školstvo, umjetnost, Caritas... ) ? Najviše su joj pri srcu 'čiste kulture', gdje je teže uprljati se; nekako sramežljivo kroči i u 'poluprljava područja kulture', dok politiku, kao kulturno dno, razmatra sa sigurne udaljenosti.« M. KNEP, Kultura kao zapreka evangelizaciji, 152.

${ }^{74}$ Usp. EG, br. 69. 
biskupima kao trajnu zadaću. Naime, inkulturacija je u evangelizaciji bitna jer je u Crkvi u velikoj mjeri prisutan tzv. integralistički model inkulturacije, koji se u povijesti pokazao lošim i koji se, unatoč tome što su ga mnogi okarakterizirali kao loš, ne napušta. Prema Milanu Knepu: »Ako je između vjere i kulture nastao ponor, ako se kultura organizirano izmaknula ispod crkvenog okrilja, valja prema kulturi krenuti. Crkva bi dakle, morala učiniti odlučnije korake u svijet kulture. $\ll^{75}$ Pastoralno i katehetsko djelovanje biskupa kao predvoditelja mjesnih Crkava mora biti poput $\gg v j e t r a$ koji nosi papiriće «: ono treba stvarati ozračje inkulturacije u kojem ljudi rade, žive i djeluju, a koje obilježava njegov društveno-religiozni milje, stanje i promjene. Papa drži da bi pastoralno i katehetsko djelovanje trebalo i moralo biti fluidno te se sastojati od aktivne, a ne reaktivne kateheze i pastorala. ${ }^{76}$ Kriza današnje kulture kriza je prosvjetiteljsko-racionalističko-kršćanskog identiteta, stoga je inkulturacija važna radi stvaranja novog identiteta današnjih kršćana. Papa emeritus Benedikt XVI. smatra kako ne smijemo ispuštati iz vida marginalizaciju, subjektivizaciju i getoizaciju božanskoga i svetoga, odnosno samoga Boga u današnjoj kulturi, jer za posljedicu takvo stanje ima »odstranjivanje kršćanstva ne samo iz državnoga života, nego i iz života građanskog društva $\ll 77$. Posljedica, istovremeno i cijena toga procesa, jest dezorijentiranost savjesti kršćana te nastanak kulture koja $\gg$ na čovječanstvu do sada nepoznat način isključuje Boga iz javne rasprave $\ll{ }^{78}$. Isti papa kaže da ako je $\gg$ Bog protjeran iz znanstvenoga područja, religija je protjerana iz ljudskoga života. Ako je moral izbačen iz prava, onda su vrijednosti izbačene iz naših zakona. Ako znanost i tehnika mogu bez ograničenja, napredak može biti slijep i destruktivan $\ll^{79}$, jer su nestali temelji identiteta. U tom smislu Benedikt XVI. smatra kako u potrazi za identitetom treba poći od temelja, a to je »pravo na individualnu slobodu i na

\footnotetext{
${ }^{75}$ Usp. M. KNEP, Kultura kao zapreka evangelizaciji, 152.

${ }^{76}$ Teolog Špiro Marasović vrlo je precizno i sadržajno opisao što je na našim prostorima aktivna, a što reaktivna kateheza. Aktivna kateheza znači crkvenu djelatnost u kojoj se Evanđelje ne $\gg$ priljepljuje $\ll$, nego »ukorjenjuje u dotičnu kulturu «. Nije parazit, nego mijenja izvornošću vlastitih sokova, te se dubinski ukorjenjuje u kulturno tkivo, prožimajući ga u korijenu; »re-aktivna kateheza « ima osobinu vječno »analizirati situaciju « - polazi od povijesne zamršenosti. Inkulturacija poprima i karakterizira reakcijsko obilježje, budući da ne može više stvarati, nego samo reagirati... Kad ne možemo više stvarati zbog vlastite nesposobnosti, takva kateheza prepušta. Najviše što reaktivna kateheza može postići jest akomodacija, nikako inkarnacija i inkulturacija. Akomodacija je samo prikriveni raskorak između kateheze i kulture, ali njegovo nadilaženje. Iza akomodacije ostaje vjera kao inflacijska pojava, ostaje dvostruki moral, dvostruki život, vjera kako ideologija. Usp. Š. MARASOVIĆ, Inkulturacija kateheze u socijalizam, 7.-9.

${ }_{77}$ Usp. J. RATZINGER, Kršćanstvo i kriza kultura, Split, 2008., 10.

${ }^{78}$ Usp. isto.

${ }^{79}$ Usp. isto, 13.
} 
izražavanje bez nametanja, barem dok ta sloboda ne povrijedi pravo drugoga. $\ll^{80}$ U svijetu beskrupuloznog kapitalima, diktature relativizma, cinizma današnje agresivne sekularizacije, materijalizma, selfie kulture, anarhizma, političkog moralizma, ateizma, subjektivizma, egoizma, individualizma, terorizma na svim razinama, a posebno na kulturnoj, pretjerane brige za prostore osobne slobode, depersonalizirane subjektivne duhovnosti, ${ }^{81}$ prometejskog neopelagijanizma i antropocentričkog imanentizma, ${ }^{82}$ prema papi Franji, izrazito je teško i zahtjevno pastoralno i katehetski djelovati, odnosno evangelizirati, posebice reći $\gg$ da « izazovu misijske duhovnosti. On uočava kako su i sami pastoralni djelatnici, uključujući i posvećene osobe, sve naglašenije prožeti usredotočenošću na prostore osobne slobode i individualizma, a zahvaćaju ih kriza identiteta i gubitak žara. ${ }^{83}$ Autoritet nekadašnje kulturne elite i moralnih vođa doživio je propast jer su pojedine vrijednosti tradicionalne religioznosti jednostavno nestale. Život po tradicionalnim shemama svakodnevno se preispituje i kritizira. Takva nesigurnost ima za posljedicu slabljenje veza s Crkvom kao institucijom, sve izraženije pribjegavanje privatiziranju Boga, sve naglašeniji i prisutniji indiferentizam koji je zapravo prešutni ateizam, sve prisutniji u mjesnim Crkvama i župnim zajednicama. Današnji se dušobrižnici nalaze u nezavidnim okolnostima zbog poslanja, službe, mjesta i uloge koju imaju, budući da su svjetonazorska i kulturna zbivanja i zbilja često obilježeni negativnim i nepomirljivim stavom prema vjeri i Crkvi. U takvoj situaciji Duhom Svetim prožeti evangelizatori - biskupi - pozvani su biti blagovjesnicima koji mole i rade, a to znači da ih neće zahvatiti nevjerica s obzirom na uspjeh, osjećaj nestanka vjere u Boga i Crkvu, gubljenje nade u mogućnost razvijanja bilo kakvog uspjeha. Naprotiv, snagom i zahtjevima Ljubavi - logikom utjelovljenja - pozvani su u pastoralnom i katehetskom smislu biti originalne osobnosti prožete alternativnim nastojanjima, pogledima, željom i radom, biti navjestiteljima koji potiho mijenjaju i stvaraju novu kulturu koja želi Evanđelje u svojim temeljima. Iščitavajući dokumente pape Franje, posebice pobudnicu Evangelii gaudium, mogu se prepoznati osnovne značajke inkulturacije kao bitne dimenzije biskupske pastoralne i katehetske službe:

\footnotetext{
${ }^{80}$ Usp. isto, 49.

${ }^{81}$ Usp. EG, br. 90.

${ }^{82}$ Usp. isto, br. 94.

${ }^{83}$ Usp. isto, br. 78-80.
} 
- Nužnost i ideal polaska od aktivnog do reaktivnog ${ }^{84}$ pastoralno-katehetskog djelovanja te njime i inkulturacijom ${ }^{85}$ utjecati na antikulturalizam suvremene kulture te akomodirano pastoralno i katehetsko djelovanje. ${ }^{86}$

- Sposobnost nadvladavanja ateističke i antieklezijalno obojene kulture, prožete privatnim i kolektivnim materijalizmom i egoizmom, suvremeni pastoralni djelatnici mogu probuditi jedino misijskim žarom i zanosom ${ }^{87}$ te aktivnom katehezom i tako se nametnuti kao jedan od nositelja ne samo religioznih nego i društvenih događanja.

- U pastoralno-katehetskom kontekstu izbjegavati $\gg$ djelovanje dviju krajnosti ${ }^{88}$ od kojih je ovdje potrebno odstupiti: $s$ jedne strane, neprihvaćanje novoga i istovremeno pastoriziranje i katehiziranje starim metodama, načinima i planovima i, s druge strane, panično-nekritičko prihvaćanje gotovo svih inicijativa bez pastoralno-sociološke prosudbe. ${ }^{89}$ To znači da pastoralno-katehetsko djelovanje mora sačuvati svoju izvornost, originalnost, inicijativu i sposobnost da ugrađuje Radosnu vijest u određeno društvo i kulturu, pri čemu ne treba djelovati oportuno.

- Biskupi će na inkulturaciju Evanđelja u današnje društvo uvelike utjecati poticanjem na glavne zadaće pastorala i kateheze, uvođenjem i poticanjem na nove oblike žive i stvarne zauzetosti, osobito na području caritasa: ohrabrivanjem za svjedočanstva, osobnu zauzetost i konkretno crkveno djelovanje. ${ }^{90}$ Živom i stvarnom zauzetošću stvarat će se kultura susreta i brige za potrebite, siromašne, napuštene i obespravljene. ${ }^{91}$

- Duhom Svetim prožetom evangelizacijom biskupi su dužni nadići »seoski sindrom pastoralno-katehetskog djelovanja $\ll{ }^{92} \mathrm{i} \gg$ duhom Isusa građanina $\ll$ stvarati

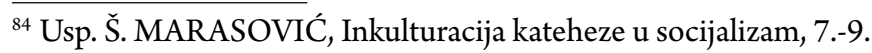

${ }^{85}$ Inkulturacija ne bi smjela biti adaptacija katehetskog vokabulara, nego ucjepljenje u konkretan način života i smisao, sadržaj.

${ }^{86}$ Usp. EG, br. 81-91.

${ }^{87}$ Usp. isto, br. 79.

${ }^{88}$ Usp. F. FRANIĆ, Suvremena kateheza na Rimskoj sinodi, u: Crkva u svijetu 13(1978.)3, 239.-244., ovdje 243.

${ }^{89}$ Usp. EG, br. 81.

${ }^{90}$ Usp. DRUGI VATIKANSKI KONCIL, Gaudium et spes. Pastoralna konstitucija o Crkvi u suvremenom svijetu (7. XII. 1965.), br. 8-9, u: Dokumenti, Zagreb, ${ }^{4} 1986$.

${ }^{91}$ Usp. EG, br. 177.

${ }_{92}$ Autor rada, proučavajući dokumente pape Franje, posebice pobudnicu Evangelii gaudium, osobno je izraze autoreferencijalnost, tradicionalizam, depersonalizirana subjektivna duhovnost, prometejski neopelagijanizam, antropocentričkog imanetizma, nazvao »seoskim sindromom pastoralokatehetskog djelovanja «, odnosno »građanskim sindromom pastoralno-katehetskog djelovanja $\ll$. Razlozi za upravo taj izraz objašnjeni su u samom tekstu rada. 
novu duhovnost, svjetonazore i kulturu. Naime, kada papa Franjo govori o prisutnim suvremenim nepravilnostima kao što su autoreferencijalnost, tradicionalizam, depersonalizirana subjektivna duhovnost, prometejski neopelagijanizam i antropocentrički imanentizam, zapravo govori o zaokruženom načinu ljudskog, kršćanskog razmišljanja, življenja i djelovanja. ${ }^{93}$ Seoski način rada, djelovanja i razmišljanja uvelike je zaokružen, jer se uvijek točno zna tko što i kako treba činiti, koji su ciljevi, koje su posljedice, zasluge i rezultati. Tako su i naši pastoralno-katehetski planovi u mentalnom sklopu često zaokruženi: navedeni su jasni izazovi, područja, razrađeni planovi, ciljevi, sredstva, i na kraju, očekivani rezultat. Za razliku od farizeja koji su »seoski pastorizirali i katehizirali «, Isus nije »seoski « pastoralno-katehetski djelovao, zbog čega je od spomenutih bio osuđen, nego $\gg$ građanski $\ll,{ }^{94}$ odnosno otvoreno: često je bez očekivanog rezultata stvarao nove odnose, novi duh, oplemenjivao postojeće, nadilazio zastarjelo poimanje koje je nerijetko više štetilo i gušilo poimanje i shvaćanje tadašnjeg čovjeka (usp. Lk 24, 25). Dakle, na način otvorenosti i nezaokruženosti Isus je akcijom i kontemplacijom stvarao novi svijet, nov pristup ljudima i Bogu, nov način djelovanja, novu kulturu. Stoga, inkulturacija Evanđelja ne može biti učinkovita »seoskim pastoralno-katehetskim pristupom « u kojem je sve zaokruženo, očekivano i unaprijed određeno, nego »građanskim $\ll$, otvorenim za novo, za prihvaćanje novonastalih okolnosti, za nov duh, zanos, žar. ${ }^{95}$

- Čovjek današnje kulture osuđen je biti brojem u matičnom uredu, na poslu, često $i$ u Crkvi, 'anonimac' na ulici, a stvaranju takvoga ozračja pridonijela su, među ostalim, i sredstva društvenoga priopćavanja i masmediji. Pojedinci su u masi izolirani, odvojeni, otuđeni i osamljeni, a među njima nema nikakve interakcije zbog čega danas mnogi ne prihvaćaju pastoralne ponude. $U$ tom smislu inkulturaciju i pastoralno-katehetsko djelovanje danas ne možemo zamisliti bez korištenja i služenja masmedijima i sredstvima društvenog priopćavanja. Biskupske konferencije na nacionalnoj i biskupi na regionalnoj razini dužni su i pomoću spomenutih sredstava evangelizirati, pastoralno i katehetski djelovati. Ukoliko bi Crkva ostala po strani s obzirom na sredstva društvenoga priopćavanja i medije, postoji realna opasnost da mali broj ljudi, služeći se njima, nametne ostatku svoju prizmu, stav i ukus obojen ideološko-političkim, religioznim i kulturnim bojama.

${ }^{93}$ Usp. isto, br. 94.

${ }^{94} \mathrm{Za}$ jasnije razumijevanje navedenih pastoralnih pristupa usp. S. NIMAC, Pastoral grada, Lepuri Split, 2008., 5.-126.

${ }^{95}$ Promišljanja teologa raznih provenijencija idu u pravcu evangelizacijske $\gg$ malograđanštine $\ll$. Ona bi bila najpoželjnija i najprihvatljivija, budući da je sinteza starog i novog, međutim, ona zbog svoje trenutnosti zadovoljenja duhovnoga, na duljoj relaciji kršćane »ostavlja gladnima i žednim za Bogom « (usp. Ps 42), te zbog toga nije trajno evangelizacijsko-pastoralno-katehetsko rješenje. 


\section{Socijalna dimenzija biskupske pastoralno-katehetske službe}

Evangelizacija je uprisutnjavanje Božjeg kraljevstva u svijetu, ${ }^{96}$ koje posjeduje neizbježnu socijalnu dimenziju, budući da je konkretizirana Kristova ljubav njegov sadržaj i središte navještaja. Kristovo otkupljenje ima socijalno značenje jer Bog ne otkupljuje i ne spašava samo pojedinu osobu, već i društvene odnose među ljudima (usp. Mt 25, 31-46). Neraskidiva povezanost između prihvaćanja navještaja i konkretne očitovane bratske ljubavi izražena je u mnogim Isusovim djelima i riječima (usp. Mt 25, 4; Iv 5, 1-18; Mk 3, 1-6; Mt 12, 1-8, Mk 2, 23-28; Mt 12, 11 ...). Osobni odnos s Bogom i stvarna bratska ljubav habitus su evangelizacije. Naglašavajući socijalnu dimenziju biskupsko-katehetske službe, papa Franjo pokazuje da je na tragu poimanja evangelizacije pape Pavla VI.: »Evangelizacija ne bi bila potpuna kad ne bi vodila računa o stvarnim i trajnim odnosima koji postoje između Evanđelja te čovjekovog osobnog i društvenog života. $\ll{ }^{97}$ Biskupi su, prema papi Franji, kao prvi evangelizatori u mjesnim Crkvama, pozvani usmjeravati Crkveni nauk i djelovanje prema socijalnim dimenzijama, inkorporirajući Kompendij socijalnog nauka Crkve u njima poslanim i dobro poznatim krajevima, mjesnim Crkvama, ${ }^{98}$ razvijajući, osnivajući, podržavajući i stvarajući strukture, ustanove, institucije koje će uklanjati postojeće korumpirane, opresivne i neučinkovite strukture u rješavanju posebno prisutnog siromaštva. ${ }^{99}$ Papa Franjo, koji je od mnogih prozvan 'papom siromašnih', biskupe posebno poziva da se u razvijanju i njegovanju socijalne dimenzije evangelizacije ne zadržavaju samo na »osiguravanju hrane, doličnog života i napretka «, nego da ukazuju i na korijene siromaštva, na strukturalne uzroke nejednakosti. Kao pozitivan primjer ističe brazilske biskupe ${ }^{100}$ koji su svojevremeno uputili javnosti apel u kojem ističu kako žele »preuzimati svakoga dana radosti i nade, tjeskobe i žalosti brazilskog naroda, osobito stanovništva gradskih predgrađa i ruralnih područja koje nema zemlje, krova nad glavom, kruha i zdravstvene skrbi, riječju obespravljenoga. Promatrajući njegove bijede, slušajući njegove vapaje i poznavajući njegovu patnju, sablažnjava nas spoznaja da postoji dovoljno hrane za sve i da je glad posljedica loše raspodjele hrane i prihoda. Problem još više otežava uvriježena navika rasipanja. ${ }^{101}$ Prema istom papi, jedna od socijalnih dimenzija evangelizacije leži i u zdravoj distanciranosti biskupa od politike bilo koje provenijencije. Isusova distanca od tadašnjih vlasti za biskupe mora predstavljati uzor

\footnotetext{
${ }^{96}$ Usp. EG, br. 176-177.

${ }^{97}$ PAVAO VI., Evangelii nuntiandi, Zagreb, 2000., br. 25.

${ }^{98}$ EG, br. 184.

${ }^{99}$ Usp. isto, br. 179.

${ }^{100}$ Usp. isto, br. 202.

${ }^{101}$ Isto, br. 191.
} 
kojeg su svi pozvani slijediti (usp. Mk 10, 42-45). Papa podsjeća kako se socijalna dimenzija evangelizacije očituje i u potrebi Crkve da i sama bude siromašna kako bi bila autentična, jer je samo siromašna Crkva, lišena svih bogatstava, najbliža Kristovoj Crkvi. ${ }^{102}$ Temelj takvog stava papa Franjo pronalazi u činjenici Isusova rođenja među životinjama, poput djece najsiromašnijih, u prikazanju u Hramu s dvije golubice, što je bio prinos onih koji si nisu mogli priuštiti ni janje (usp. Lk 2, 24), u njegovu poistovjećenju sa siromašnima ( $\mathrm{Mt} 25,35$ ). Za Crkvu je opredjeljenje za siromašne prvotno teološka, a onda kulturna, sociološka i bilo koja druga kategorija, stoga socijalnu dimenziju evangelizacije možemo definirati kao punomoć Crkve u nemoći vlasti Crkve. ${ }^{103} \mathrm{U}$ tom kontekstu biskupi su pozvani biti glas obespravljenih, prvotno usmjeravanjem pozornosti na siromašne, a onda i osobno aktivnim zauzimanjem. ${ }^{104}$ Nadalje, socijalna dimenzija evangelizacije biskupa, prema papi Franji, očituje se u brizi za odgoj, osiguravanju zdravstvene skrbi, dostojanstvu rada, u brizi za pravednu plaću, u dostojanstvu ljudskoga života svakoga čovjeka, u brizi za izbjeglice, selitelje, prognanike. ${ }^{105} \mathrm{Kršćani}$, posebice njihovi pastiri, pozvani su u sebi i oko sebe pobjeđivati današnji individualistički, egoistični, ravnodušni mentalitet, kulturu i retoriku, osobnim zauzimanjem činiti suvremeni svijet humanijim, plemenitijim, ravnopravnijim i pravednijim ${ }^{106}$ te evangelizacijom doprinositi socijalnom dijalogu ${ }^{107}$ kao bitnoj dimenziji mira i općeg dobra u svijetu. ${ }^{108}$

\section{Umjesto zaključka}

U svijetu beskrupuloznog kapitalima, diktature relativizma, cinizma današnje agresivne sekularizacije, selfie kulture, anarhizma, političkog moralizma, ateizma, subjektivizma, egoizma, individualizma, terorizma na svim razinama, a posebno na kulturnoj, pretjerane brige za prostore osobne slobode, depersonalizirane subjektivne duhovnosti, prometejskog neopelagijanizma i antropocentričkog imanentizma, prema papi Franji, izrazito je teško i zahtjevno vršiti i ostvarivati svaku službu u Crkvi, a posebice biskupsku te pastoralnu i katehetsku dimenziju te službe.

\footnotetext{
${ }^{102}$ Usp. isto, br. 197.

${ }^{103}$ Usp. P. HENRICI, Punomoć u nemoći: vlast Crkve, u: Svesci 13(1984.)55, 63.-66.

${ }^{104}$ Usp. isto, 6.

${ }^{105}$ Usp. EG, br. 192; br. 210.

${ }^{106}$ Kao primjer ističe biskupe Konga koji u okolnostima multietničnosti nastoje pomoći svima u jedinstvu, miru i pomirenju. (Usp. isto, br. 230.)

${ }^{107}$ Usp. H. J. POTTMEYER, Dijaloške strukture u Crkvi i teologija zajedništva (Communio) Drugoga vatikanskog koncila, 20.-31.

${ }^{108}$ Prema papi Franji evangelizacija sadržava tri razine: dijalog s državama, dijalog s društvom, kulturom i znanosti, te dijalog s vjernicima drugih konfesija. (Usp. EG, br. 238.)
} 
Nadalje, prema papi Franji, Crkva nije samo događanje, nego i institucija pa, osim ministerijalne, ima i institucionalnu dimenziju. Služba i karizma biskupske službe ne mogu se promatrati odijeljeno jedna od druge jer biti biskupom mjesne Crkve znači služiti i primljeni dar dati, darivati i pružati cijeloj od Krista darovanoj zajednici. Pastoralna i katehetska dimenzija biskupske službe uvijek je služba Evanđelju i bližnjemu. Ona treba biti poput $\gg$ drevna izvora iz kojega izbija svježa i živa voda $\ll .{ }^{109}$ $\mathrm{U}$ tom smislu Papina je osobita briga putem inkulturacije i socijalne dimenzije evangelizacije rekontekstualizirati crkveni nauk u korist pastoralne misijske Crkve. Prvi korak trebaju učiniti biskupi, suočavajući se sa suvremenim kolonijalističkim i imperijalističkim neokulturnim kontekstom, liječeći svoje biskupije od suvremenih bolesti te napuštajući logiku pastoralnog i katehetskog samoranjavanja. Devijacije biskupske službe koje su navedene, autoritativnost, demokratičnost, tehnokratsko življenje biskupske službe i vjerska osamljenost, moraju postati prošlost u svakom, osobito u pastoralnom i katehetskom vidu službe, jer guše djelovanje Duha Svetoga. Biskup koji obavlja službu zatvarajući se u samoga sebe i prepuštajući pastoralno i katehetsko djelovanje drugima bez osobne odgovornosti, koji robuje vlastitoj autoritativnosti i prošlosti, usredotočen je na sitna pravila ponašanja $i \gg$ bezglavo trči od obveze do obveze, ne prepoznavajući bit i narav biskupske službe, ${ }^{110}$ prema papi Franji, izdaje svoj identitet. ${ }^{111}$ Za papu Franju, nova evangelizacija, Crkva koja evangelizira, a time i pastoralna i katehetska služba biskupa, uvijek mora polaziti od molitve i zazivanja ognja Duha Svetoga po uzoru na apostole u dvorani Posljednje večere. Samo istinski odnos s Bogom omogućuje nam izlazak iz vlastitih zatvorenosti i otvoreno (parresia) naviještanje Evanđelja, dok bez molitve naše djelovanje ostaje prazno i naše naviještanje nema dušu jer nije oživljeno Duhom. ${ }^{12}$ Želi li biskup biti poslušan Duhu, preostaje mu osluškivati njegove poticaje u svakodnevnici i navedenim okolnostima Božjega naroda. Naime, biskup ne može izmisliti ni stvoriti Crkvu i Božji narod $\mathrm{u} \gg$ čisto isusovskom «smislu, nego je pozvan i dužan naviještati i katehizirati suvremenom ranjenom čovjeku Radosnu vijest, onakav kakav je i sam - ranjen i izranjavan, ali usmjeren $\mathrm{k}$ Učitelju koji ga želi izliječiti i ozdraviti (usp. Mk 1, 40-45). Pastoralna i katehetska dimenzija biskupske službe za papu Franju posebno dolazi do izražaja u raspoznavanju karizmi koje je biskup pozvan institucionalizirati: budući da su karizma i institucija poput drveta koje ne

\footnotetext{
${ }^{109}$ Usp. C. van VLIET, Yves Congar: služba i karizma, 73.

${ }^{110}$ Nerijetko se stječe dojam da današnji ne samo vjernici, nego osobito njihovi pastiri (a time i vjernici) u pastoralnom i katehetskom nastojanju »od drveća ne vide šumu «.

${ }^{111}$ Usp. http://w2.vatican.va/content/francesco/hr/audiences/2014/documents/papa-francesco 20141112_udienza-generale.html (14.6.2017.)

${ }^{112}$ Usp. http://w2.vatican.va/content/francesco/hr/audiences/2013/documents/papa-francesco_ 20131120_udienza-generale.html (11.6.2017.)
} 
može rasti i egzistirati bez soka i žila, tako ni pastoralno i katehetsko djelovanje ne može funkcionirati bez institucionaliziranosti karizmi te posebice bez konkretne socijalne zauzetosti i brige za konkretnog čovjeka u potrebi. 


\title{
THE PASTORAL-CATECHETICAL DIMENSION OF THE BISHOP'S MINISTRY IN THE DOCUMENTS OF POPE FRANCIS
}

\author{
Stanislav ŠOTA*
}

Summary: The paper analyzes the understanding of the pastoral and catechetical dimension of the bishop's ministry in the documents of Pope Francis. In four parts, the paper presents the content and characteristics of bishop's pastoral and catechetical activities, the mode of its realization and concrete contribution. Speaking primarily of the Jesus-like dimension of bishop's pastoral-catechetical activity, the paper analyzes, it $\gg$ stops $\ll$ on Jesus' face as the image and the synonym of bishop's necessary evangelizing zeal, fervor and transformation. Jesus' transformed face is a call, a mission and a need for the evangelizing, pastoral and catechetical transformation. The Jesus-like face speaks about the necessity of bishops being imbued with the principles and values of Jesus, about the necessity of their testimony and concrete love rooted in pastoral and catechetical activity. The second part of the paper brings concrete tasks of bishop's ministry in the pastoral and catechetical sense: the incorporation of the Gospel in the socio-cultural environment, creating new models of pastoral-catechetical activity, promoting missionary communion, reviewing traditions, overcoming the $>$ rural syndrome $<$ in the pastoral-catechetical activity, the need to realize the bishop's ministry in the dimension of $\gg$ Jesus the Citizen $\ll$ and > going out $<$ to the peripheries, especially with a better family pastoral. In the third part, the author analyzes the pastoral-catechetical postulates of the bishop's ministry through the prism of stronger inculturation, active, rather than re-active pastoral-catechetical activity, the overcoming of atheistic and anti-ecclesial culture of modern man, the need to preserve the original ways of incorporating the Gospel in the society, and the need for a stronger pastoral and catechetical inculturational involvement of bishops in their own dioceses. The fourth part of the paper points to the social dimension of the pastoral-catechistical activity of bishops, by stressing the need for bishops' initiative to overcome evil and poverty that are present in the world, to deprive and eliminate their consequences, to point out their structural causes, with concern for ensuring health care for every person, the dignity of work, fair pay, protection of the dignity of human life, to contribute to and spread social dialogue as an essential dimension of peace and common good in the world.

Keywords: Pope Francis, pastoral and catechetical dimension of the bishop's ministry, the Jesus-like face of the bishop's ministry, inculturation, the social dimension of pastoral and catechetical activity.

\footnotetext{
* Asst. Prof. Stanislav Šota, Ph. D., Catholic Faculty of Theology in Đakovo, J. J. Strossmayer University of Osijek, P. Preradovića 17, 31400 Đakovo, Croatia, stanislav.sota@os.t-com.hr
} 